\title{
Effects of habitat management on different feeding guilds of herbivorous insects in cacao agroforestry systems
}

\author{
Samuel M. A. Novais*, Luiz E. Macedo-Reis, Wesley D. DaRocha \& Frederico S. Neves \\ Laboratório de Ecologia de Insetos, Departamento de Biologia Geral, Universidade Federal de Minas Gerais, Belo \\ Horizonte, Minas Gerais, 31270-901, Brazil; snovaisbio@gmail.com, luizmacedoreis@gmail.com, \\ wd.darocha@gmail.com, fred.neves@gmail.com
}

Recibido 07-V-2015. Corregido 15-I-2016. Aceptado 16-II-2016.

\begin{abstract}
Human pressure on natural habitats increases the importance of agroforests for biodiversity conservation. The objective of this study was to evaluate the role of cacao traditional cultivation system (CTCS) on the conservation of the herbivorous insect community when compared with a monodominant rubber agroforest, a type of agricultural system for cacao cultivation. The insects were sampled in three habitats in Southeastern Bahia, Brazil: native forests, CTCS and rubber agroforests. In each habitat, 18 plots of $10 \mathrm{~m}^{2}$ were established, and the structural measures were collected and herbivorous insects were sampled with a Malaise/window trap. The diversity of folivorous decreased with the simplification of vegetation structure, but species composition was similar among habitats. In addition to a decrease in the availability of resources in monodominant rubber agroforests, the latex present in these systems have limited the occurrence of species that cannot circumvent latex toxicity. The diversity of sap-sucking insects was similar among habitats, but species composition was similar only in the CTCS and native forest, and it was different in the rubber agroforest. We observed turnover and a higher frequency of individuals of the family Psyllidae in the rubber agroforest. The biology and behavior of Psyllids and absence of natural enemies enable their diversity to increase when they are adapted to a new host. We observed a shift in the composition of xylophagous insects in the rubber agroforest compared to that in other habitats. Moreover, this agroforest has low species richness, but high individual abundance. Latex extraction is likely an important additional source of volatile compounds discharged into the environment, and it increases the attraction and recruitment of coleoborers to these sites. We concluded that CTCS has an herbivorous insect community with a structure similar to the community found in native forests of the region, and they present a more interesting conservation strategy when compared to rubber agroforests. We also emphasized the potential risk of local pest outbreaks in rubber agroforests for both the rubber and associated cacao trees. Rev. Biol. Trop. 64 (2): 763-777. Epub 2016 June 01.
\end{abstract}

Key words: Theobroma cacao, biodiversity, land use, conservation, forest management.

Land uses that require modification of natural habitats are the main cause of biodiversity loss in the tropics (Sala et al., 2000). A simplification and homogenization of natural systems usually occur because of anthropogenic activities (Tabarelli, Peres, \& Melo, 2012) that reduce tree species richness and systematically reduce animal diversity (Stein, Gerstner, \& Kreft, 2014). In contrast, traditional agroforestry systems are considered a good strategy to conserve a significant portion of the original forest biodiversity while also meeting the economic needs of producers (Steffan-Dewenter et al., 2007). The shaded cacao (Theobroma cacao L., Malvaceae) plantation is one of these traditional systems exploited successfully in the tropics, and it is characterized by replacement of the understory of the original forest by cacao and retention of a portion of the canopy for crop shading (Rice \& Greenberg, 2000).

The main cocoa-producing region of Brazil is located within the state of Bahia, where 
the cacao traditional cultivation system (CTCS) occupies large agricultural areas (Cassano, Schroth, Faria, Delabie, \& Bede, 2008). The original vegetation formation of the region was the Atlantic Forest, one of the most impacted tropical rainforests in the world, with only $7 \%$ of its original extent remaining (Fundação SOS Mata Atlântica, Instituto Nacional de Pesquisas Espaciais, 2008). This biome has high species richness and endemism and is considered a hotspot for global biodiversity conservation (Myers, Mittermeier, Mittermeier, Fonseca, \& Kent, 2000). In the past (especially in Southern Bahia), the expansion of cacao plantations was considered the main cause of deforestation, transforming the original landscape into a mosaic of small forest fragments embedded in a CTCS matrix (Saatchi, Agosti, Alger, Delabie, \& Musinsky, 2001). However, compared with other land-use strategies that suppress or replace native forest, the CTCS have received considerable attention because of their important role in maintaining regional biodiversity (Cassano et al., 2008; Pardini et al., 2009; Sambuichi et al., 2012).

Nonetheless, the CTCS undergo agricultural management that includes canopy thinning or complete removal of the shade trees, which are replaced by more productive systems (Johns, 1999; Sambuichi et al., 2012). A major crisis struck the Brazilian cacao sector in the 1980s because of a drop in the international price of cacao and introduction of "witches' broom," a disease caused by the fungus Moniliophthora perniciosa (Peiera, Ram, Figueiredo, \& Almeida, 1990). During the economic crisis, certain producers chose to remove the shade trees from the CTCS, while others replaced the CTCS with more intensive farming systems or pastures, and other areas were simply abandoned (Alger \& Caldas, 1994; Araujo, Alger, Rocha, \& Mequita, 1998). To avoid additional losses and the bankruptcy of producers, the Cocoa Farming Plan Executive Committee (Comissão Executiva do Plano da Lavoura Cacaueira - CEPLAC) attempted to rehabilitate cacao plantations by researching new strategies and techniques, such as grafting varieties of cacao individuals resistant to witches' broom into infected trees. The CEPLAC recently recommended that native shade trees should be replaced by the exotic rubber tree, Hevea brasiliensis (Willd. ex A. Juss.) Müll. Arg., a species from the Brazilian Amazon, in order to increase farming income through latex extraction (Marques \& Monteiro, 2006).

Intensifying agricultural management by totally removing or replacing native shade trees with one or a few dominant species may negatively affect the diversity of animal groups, especially insects such as ants, butterflies (Perfecto, Mas, Dietsch, \& Vandermeer, 2003), bees (Klein, Steffan-Dewenter, Buchori, \& Tscharntke, 2002a), beetles (Bos, Steffan-Dewenter, \& Tscharntke, 2007c) and parasitoids (Sperber, Nakayama, Valverde, \& Neves, 2004). Vegetation characteristics determine ecosystem processes, including primary production and nutrient flow (Díaz et al., 2007). Therefore, structural and compositional changes in the plant community have direct effects on the associated fauna, beginning with primary consumers (Price et al., 1980; Neves, Silva, Espírito-Santo, \& Fernandes, 2014). The effects on herbivores are propagated throughout the food chain, causing changes in the abundance of organisms in other parts of the trophic web (Price et al., 1980; Polis \& Strong, 1996).

In this study, we analyzed the effects of anthropogenic changes in the form of different land-use strategies on the community structure of three feeding guilds of herbivorous insects (folivorous, sap-sucking and xylophagous). Our objective was to assess whether more heterogeneous and structurally complex habitats, such as the CTCS, retain a considerable portion of their native diversity and have a herbivorous insect community structure similar to that of native forests compared with simpler environments, such as the rubber agroforest. We tested the following predictions: $i$ - the composition of herbivorous insects is similar between the native forest and CTCS, and different from the rubber agroforest; ii- the abundance and richness of herbivorous insects are higher in 
the native forest and CTCS, and smaller in the rubber agroforests; and iii- the abundance and richness of herbivorous insects are positively determined by the percentage of shade cover.

\section{MATERIALS AND METHODS}

Study area: The study was conducted from February to March 2013 in three distinct habitats - two types of cacao agroforestry matrices and a native forest. The CTCS was constituted of cacao plantation's areas shaded by the canopy of irregularly distributed native trees, and there is little or no canopy connectivity (Fig. 1A). The rubber agroforests were typically homogeneous, with individuals regularly distributed in the environment for cacao shading (Fig. 1B).

The sampling sites were located in the cacao growing region of Southeastern Bahia in the municipality Una, which is within the Central Atlantic Forest Corridor (Fonseca, Alger, Pinto, Araujo, \& Cavalcanti, 2004). The dominant vegetation type in the region is the South Bahia coastal rainforest (Thomas, 2003), which is characterized by tall, broadleaved and evergreen trees, and many lianas and epiphytes. The climate is hot and humid and characterized by the absence of a well-defined dry season (type Af in the Köppen classification). The mean annual rainfall exceeds $1300 \mathrm{~mm}$ and may reach $1600-1800 \mathrm{~mm}$ in rainy years. The mean annual temperature is $24-25{ }^{\circ} \mathrm{C}$, with warmer periods from October to April (maximum of $38^{\circ} \mathrm{C}$ ), and colder periods from June to August (minimum $7^{\circ} \mathrm{C}$ ) (Mori, 1989).

Sampling design: Three $500 \mathrm{~m}$ transects located at least $1 \mathrm{~km}$ apart were selected in each habitat. The native forest transects were located within the Una Biological Reserve (Reserva Biológica de Una - REBIO de Una) (1), the largest Conservation Unit of the cacao growing region, which is characterized by native forest with closed canopy. The six transects in the CTCS and rubber agroforests were located in a farm complex located Southwest from the REBIO de Una: Bom Jesus Farm (2), Vera Cruz Farm (3), Valmonte Farm (4), Ardenas Farm (5) and São Nícolas Farm (6) (Table 1). A total of six traps spaced $100 \mathrm{~m}$ apart were set in each transect to sample herbivorous insects. Therefore, a total of 18 sampling traps were set up in each habitat, for a total of 54 traps.

\section{Structural characterization of the veg-} etation and shade cover: To characterize the vegetation structure, $10 \mathrm{~m}^{2}$ plots were established around the traps. In each plot, the richness and density of trees with a diameter at breast height $(\mathrm{DBH}) \geq 15 \mathrm{~cm}$ were measured and identified in field by a specialist botanic, and the height $(\mathrm{m})$ of the selected individuals was subsequently estimated. The percentage
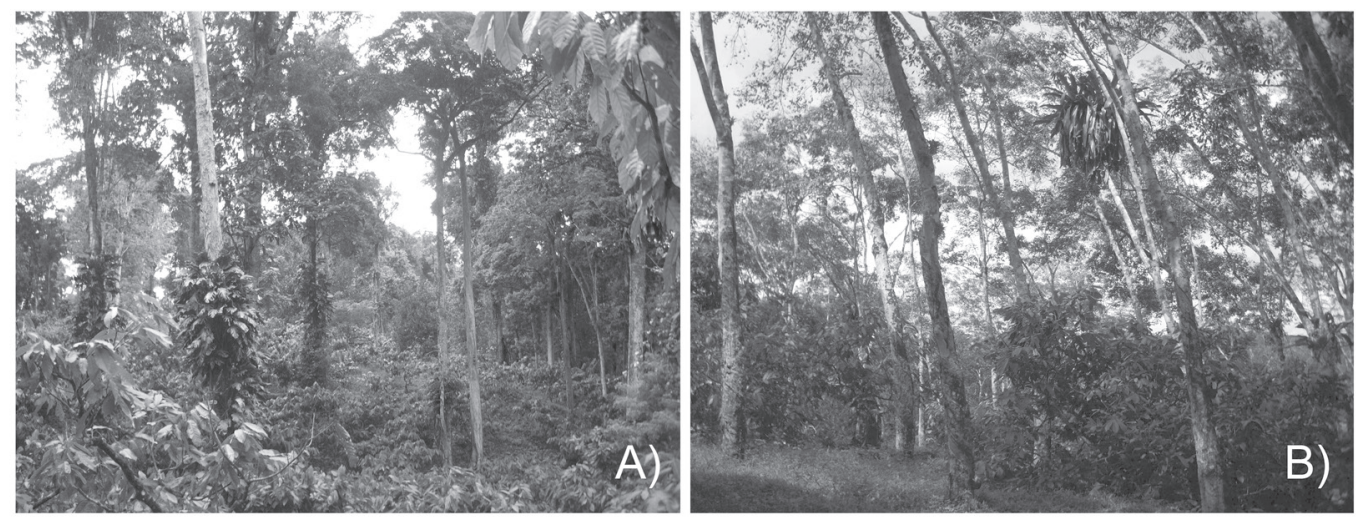

Fig. 1. Cacao traditional cultivation system shaded by native trees (A.), and agroforest rubber trees as shade trees (B.) (pictures S. M. A. Novais). 


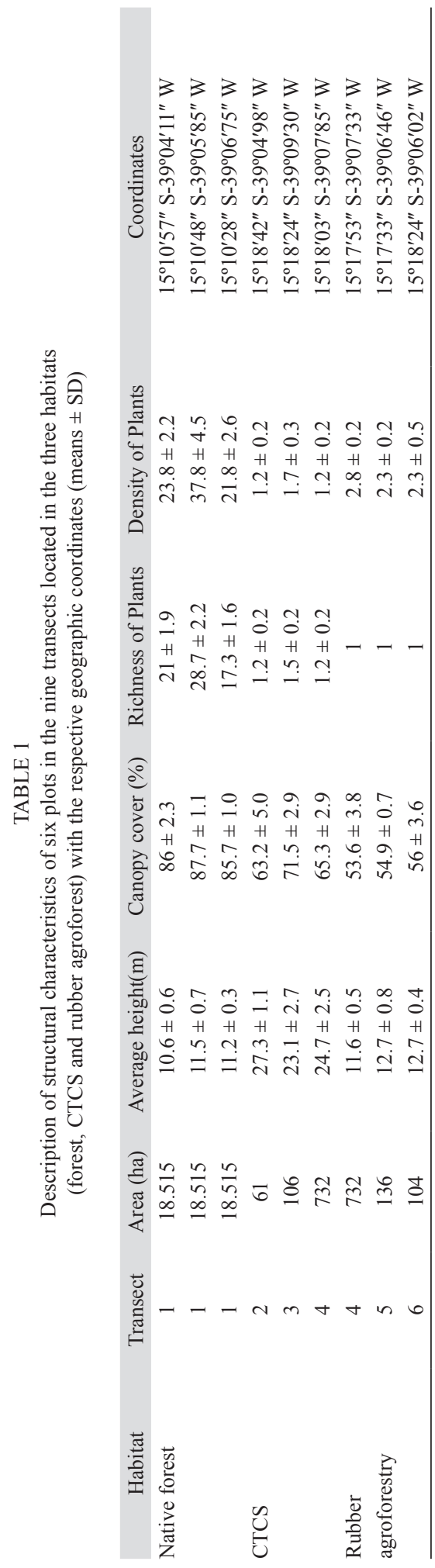

of shade cover per plot was measured from hemispherical canopy photographs taken using a digital camera with an $8 \mathrm{~mm} 180^{\circ}$ fisheye lens (Sanchez-Azofeifa et al., 2007). The percent canopy cover was estimated from these pictures using the software Gap Light Analyzer (GLA) (Frazer, Canham, \& Lertzman, 1999) (Table 1).

Sampling of herbivorous insects and classification into guilds: The insects were sampled with an aggregate Malaise/window flight intercepting trap based on the model proposed by Basset (1988). The "Malaise" portion is efficient in sampling insects with negative geotropism, and the "window" portion is efficient in sampling insects with positive geotropism (Basset, 1988). Both parts (top and bottom) end in flasks containing $70 \%$ ethanol for insect fixation, imprisonment and death. The traps were exposed for seven days $(168 \mathrm{~h} /$ trap) in the center and canopy of the plots.

The sampled herbivorous insects were grouped into three guilds according to their feeding habit - sap-sucking, folivorous and xylophagous (Weis \& Berenbaum, 1989). All of the insects belonging to families with prevailing herbivorous habits were considered herbivores (Moran \& Southwood, 1982; Neves et al., 2014). Insects belonging to the suborders Auchenorrhyncha, Sternorrhyncha and Heteroptera were considered sap-sucking herbivores, and insects belonging to the families Chrysomelidae, Curculionidae, Elateridae and Phasmidae were considered folivores. The subfamilies Platypodinae and Scolytinae (Curculionidae) and families Anobiidae and Cerambycidae were included in the guild of xylophagous herbivorous insects, which are groups that preferentially feed on wood parts or build galleries to cultivate fungi for feeding, depending directly or indirectly from the wood resource for survival. All other insects were identified using taxonomic keys (Rafael, Melo, Carvalho, Casari, \& Constantino, 2012) and separated into morphospecies based on external morphological characters. The sampled insects were deposited in the entomological collection 
of the Laboratory of Insect Ecology of the Federal University of Minas Gerais (Universidade Federal de Minas Gerais - UFMG).

The influence of habitat on the species composition of herbivore insects compositions (folivorous, sap-sucking and xylophagous) was tested using a permutational multivariate analysis of variance (PERMANOVA) (Anderson, 2001). We used Bray Curtis dissimilarity measures, and 999 permutations were generated. We also used non-metric multidimensional scaling (NMDS) to represent the results of the PERMANOVA analyses. For the NMDS, the ordination of species composition was performed using the Bray-Curtis index.

Generalized linear models (GLMs) were built to assess whether the abundance and diversity of herbivorous insects are influenced by habitat and canopy cover. The abundance and richness of folivorous, sap-sucking and xylophagous herbivorous insects were used as the response variables, and habitat and canopy cover were used as the explanatory variables. The models were subjected to an analysis of residuals to test the adequacy of the error distribution (Crawley, 2007). The minimum adequate model (MAM) was obtained by extracting non-significant terms $(\mathrm{p}<0.05)$ from the full model (Crawley, 2007); when significant differences were observed between habitats, the data were submitted to contrast analysis by aggregating levels (Crawley, 2007). If the level of aggregation was not significant and did not alter the deviance explained by the null model, the levels were pooled together (contrast analyses). All statistical analyses were conducted with $\mathrm{R}$ software (R Development Core Team, 2014).

\section{RESULTS}

A total of 2084 herbivorous insects were sampled, with 193 (9\%) belonging to the folivorous guild, 859 (41\%) belonging to the sap-sucking guild and 1032 (50\%) belonging to xylophagous guild. The specimens were distributed among 390 morphospecies, including 85 folivorous, 167 sap-sucking and 138 xylophagous herbivores. Among the folivores, the families with the greatest number of morphospecies were Curculionidae (54) and Chrysomelidae (21); among the sap-sucking herbivores, families with the greatest number of morphospecies were Cicadellidae (56) and Psyllidae (47); among the xylophagous herbivores, the subfamilies and/or families with the greatest number of morphospecies were Scolytinae (80) and Anobiidae (24) (Table 2).

The composition of herbivorous folivores insect morphospecies was similar among the habitats studied (PERMANOVA, $\mathrm{p}=0.059$, Fig. 2A). However, the CTCS have a sapsucking and xylophagous insect composition similar to that of the native forest and different from the composition of the rubber agroforest (PERMANOVA, $p=0.01$ and $p=0.0002$, Fig. $2 \mathrm{~B}$ and Fig. 2C). Individuals of the family Psyllidae were highly abundant in the rubber agroforest (216) and CTCS (150) compared with the abundance sampled in the native forest (17) (Table 2).

The abundance and richness of the three herbivorous insect guilds varied among the habitats (Table 3, Fig. 3). Folivore abundance and richness were higher in the native forest, followed by CTCS and rubber agroforest (Fig. $3 \mathrm{~A}$ and Fig. 3B). The abundance and richness of sap-sucking insects was similar among habitats ( $p>0.05$, Fig. 3 A and Fig. 3B). The abundance of xylophagous insects was higher in the rubber agroforest, followed by the CTCS and native forest (Fig. 3A); besides, the richness was higher in the CTCS and similar between the native forest and rubber agroforest (Fig. 3B).

The canopy cover effect also varied among the insect guilds. Canopy cover positively affected the abundance and richness of folivorous insects (Table 3, Fig. 4A, Fig. 4B), whereas it negatively affected the abundance and richness of sap-sucking insects (Table 3, Fig. 4C, Fig. 4D) and the abundance of xylophagous insects (Table 3, Fig. 4E), which did not show an effect for richness (Fig. 4F). 
TABLE 2

Morphospecies richness (Rich.) and abundance (Ab.) of herbivorous insects (folivorous, sap-sucking and xylophagous) sampled in two cacao agroforestry matrices and Atlantic Forest in the municipality of Una, Southern Bahia

\begin{tabular}{|c|c|c|c|c|c|c|c|c|}
\hline \multirow{2}{*}{ Guild/Taxon } & \multicolumn{2}{|c|}{ FOREST } & \multicolumn{2}{|c|}{ CTCS } & \multicolumn{2}{|c|}{ RUBBER } & \multicolumn{2}{|c|}{ TOTAL } \\
\hline & Ric & $\mathrm{Ab}$ & Ric & $\mathrm{Ab}$ & Ric & $\mathrm{Ab}$ & Ric & $\mathrm{Ab}$ \\
\hline \multicolumn{9}{|l|}{ Xylophagous /Coleoptera } \\
\hline Anobiidae & 17 & 44 & 10 & 56 & 4 & 13 & 24 & 113 \\
\hline Cerambycidae & 4 & 5 & 12 & 18 & 5 & 36 & 16 & 59 \\
\hline Curculionidae (Platypodinae) & 5 & 8 & 15 & 32 & 6 & 10 & 18 & 50 \\
\hline Curculionidae (Scolytinae) & 35 & 89 & 44 & 261 & 31 & 460 & 80 & 810 \\
\hline \multicolumn{9}{|l|}{ Folivorous/Coleoptera } \\
\hline Chrysomelidae & 15 & 73 & 7 & 16 & 0 & 0 & 21 & 89 \\
\hline Curculionidae & 30 & 39 & 24 & 39 & 9 & 16 & 54 & 94 \\
\hline Elateridae & 4 & 4 & 4 & 4 & 1 & 1 & 9 & 9 \\
\hline \multicolumn{9}{|l|}{ Phasmatodea } \\
\hline Phasmidae & 1 & 1 & 0 & 0 & 0 & 0 & 1 & 1 \\
\hline \multicolumn{9}{|l|}{ Sap-sucking/Hemiptera } \\
\hline \multicolumn{9}{|l|}{ Auchenorrhyncha } \\
\hline Achilidae & 9 & 94 & 9 & 58 & 5 & 8 & 18 & 160 \\
\hline Achilixiidae & & & & & 1 & 1 & 1 & 1 \\
\hline Aetalionidae & & & 1 & 1 & & & 1 & 1 \\
\hline Cicadellidae & 20 & 51 & 33 & 58 & 19 & 77 & 56 & 186 \\
\hline Cicadidae & & & 3 & 5 & 1 & 1 & 3 & 6 \\
\hline Cixiidae & & & 1 & 1 & & & 1 & 1 \\
\hline Derbidae & & & 1 & 1 & & & 1 & 1 \\
\hline Issidae & 1 & 1 & & & & & 1 & 1 \\
\hline Membracidae & & & 4 & 4 & 1 & 1 & 5 & 5 \\
\hline \multicolumn{9}{|l|}{ Sternorrhyncha } \\
\hline Psyllidae & 10 & 17 & 25 & 150 & 22 & 216 & 46 & 383 \\
\hline \multicolumn{9}{|l|}{ Heteroptera } \\
\hline Cydnidae & & & 2 & 3 & 1 & 1 & 2 & 4 \\
\hline Lygaeidae & 4 & 4 & 3 & 13 & 9 & 25 & 12 & 42 \\
\hline Miridae & 1 & 1 & 1 & 1 & & & 2 & 2 \\
\hline Pyrrhocoridae & & & 1 & 1 & & & 1 & 1 \\
\hline Tingidae & & & 1 & 1 & & & 1 & 1 \\
\hline Not identified & 4 & 11 & 11 & 27 & 8 & 26 & 16 & 64 \\
\hline TOTAL & 160 & 442 & 212 & 750 & 123 & 892 & 390 & 2084 \\
\hline
\end{tabular}

\section{DISCUSSION}

Land use and agricultural intensification have caused a significant shift in community structure and/or composition of herbivorous insects. We observed that habitat changes differently affected the herbivorous insect guilds. These results were supported by studies that have reported different responses of distinct arthropod taxa (Perfecto et al., 2003; Schulze et al., 2004; Bos et al., 2007a; Kessler et al., 2009) and feeding guilds (Klein, Steffan-Dewenter, \& Tscharntke, 2002b; Wilby et al., 2006) to changes in land use.

Habitat homogenization through the use of exotic species (rubber tree) as shade trees did not affect the composition of folivore insect species. Although few folivore species are shared between the rubber agroforest and the other habitats, folivore species turnover among 


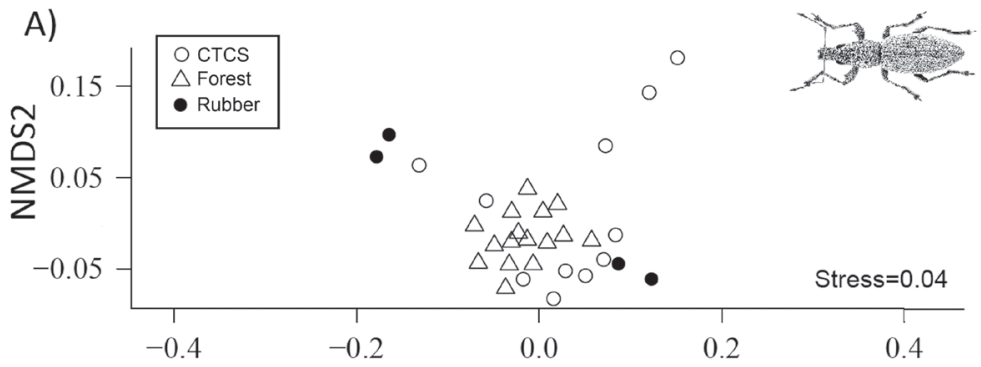

B)
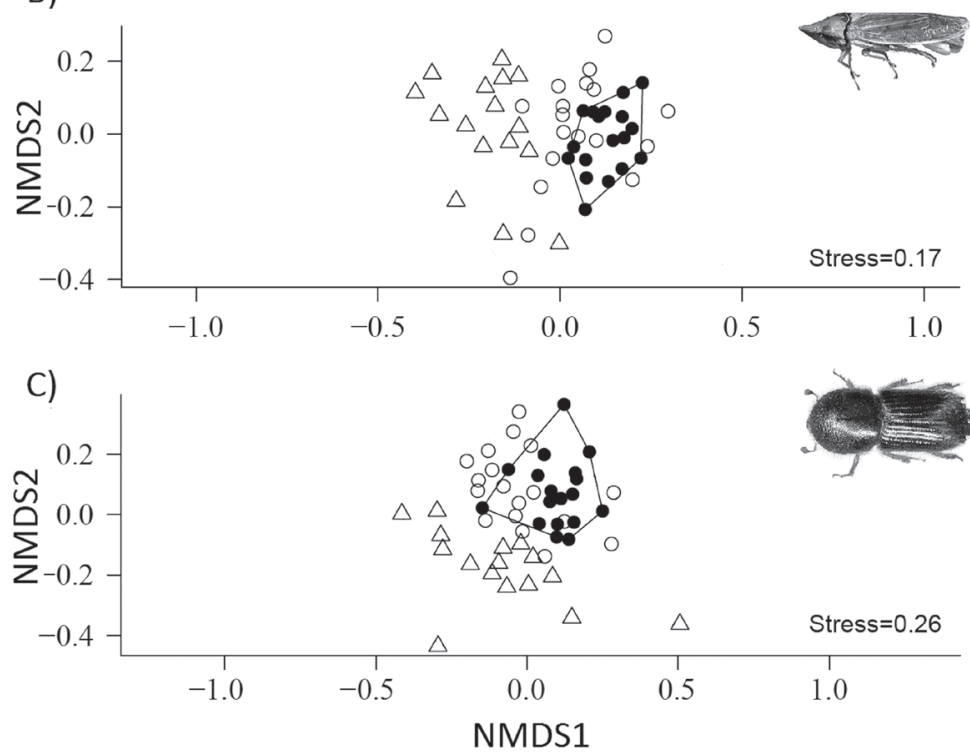

Fig. 2. Non-metric multidimensional scaling (NMDS) for the ordination of the folivorous (A.), sucking (B.) and xylophagous (C.) herbivorous insect guilds that were sampled in two agroforestry matrices (CTCS and rubber) and Atlantic Forest in the cacao growing region of southeastern Bahia, municipality of Una, Brazil. A significant difference in species composition $(p<0.05)$ among the rubber matrix, CTCS matrix and the Atlantic forest was observed for the sucking and xylophagous insects from PERMANOVA analyse.

the traps was observed, and many rare species were present. In general, the colonization of an exotic plant is determined by the pool of potential colonizing insect species (Strong, Lawton, \& Southwood, 1984). Additionally, the phylogenetic proximity between the exotic species and native flora is an important factor for insect colonization because of the intrinsic characteristics shared by the plant hosts (Agrawal \& Kotanen, 2003). Only $14 \%$ of all tropical plant species produce latex (Lewinsohn, 1991), which is a distinct characteristic of the rubber tree (Hevea brasiliensis). This compound is associated with plant defense against herbivory, but herbivorous insects can circumvent latex toxicity (Agrawal \& Konno, 2009), such as beetles of the family Curculionidae (Agrawal \& Van Zandt, 2003).

Habitat homogenization and percent canopy cover reduction changed the folivore guild community structure, although the folivore species composition was not affected. Folivore abundance and richness decreased between the native forest, a naturally heterogeneous habitat, and the CTCS and rubber agroforest. The folivore insect diversity usually increases 

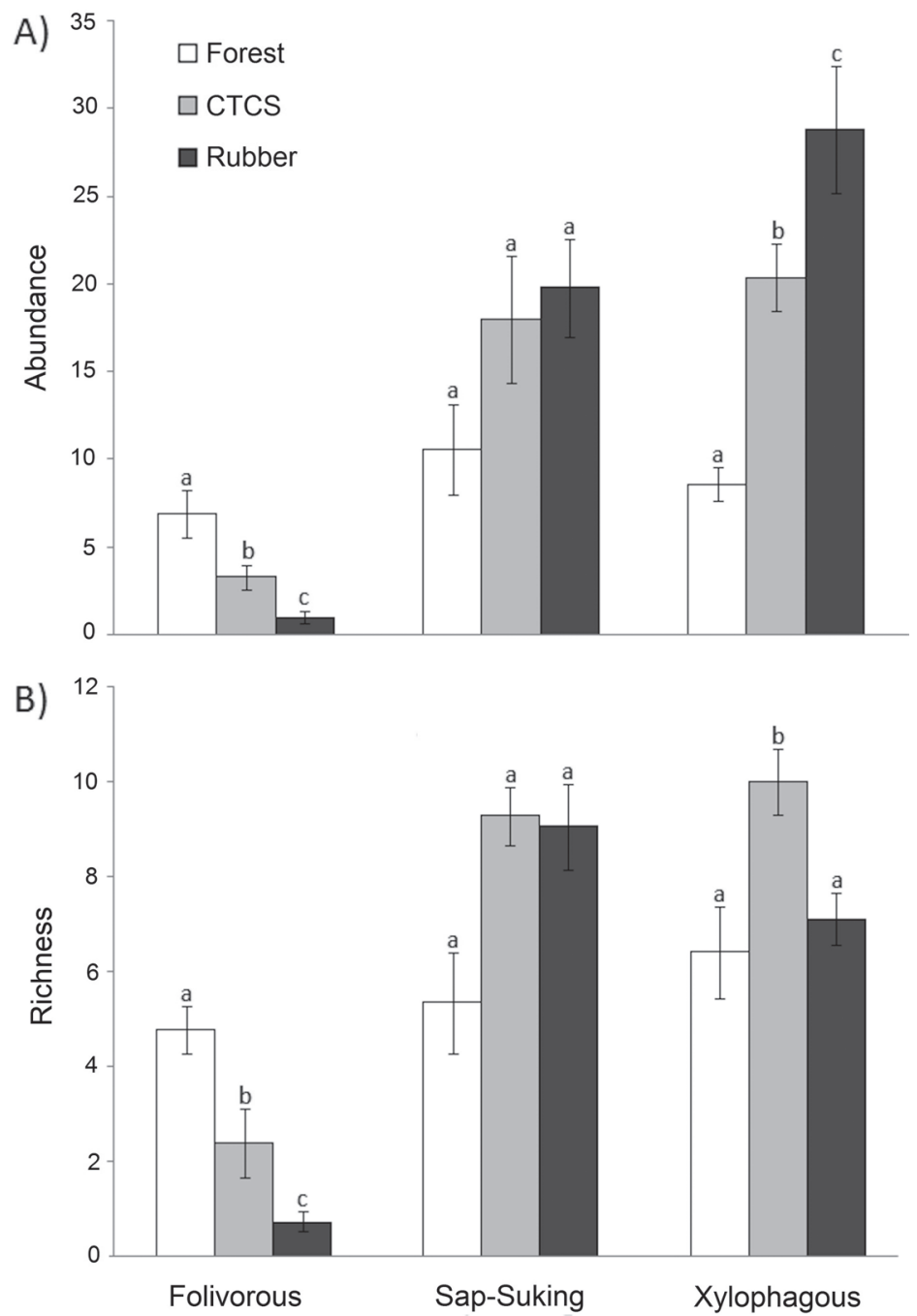

Fig. 3. Mean abundance (A.) and richness (B.) of herbivorous insects (folivorous, sucking and xylophagous) estimated using trap $( \pm \mathrm{SE})$ samplings in two agroforestry matrices (CTCS and rubber) and Atlantic Forest, located in the cacao growing region of southeastern Bahia, municipality of Una, Brazil. Different letters represent significant differences among groups $(\mathrm{p}<0.05)$.

with an increase in leaf availability, plant richness and abundance (Basset, Novotny, Miller, \& Kitching, 2003; Neves, Sperber, Campos, Soares, \& Ribeiro, 2013) and host nutritional quality (Awmack \& Leather, 2002; Cornelissen \& Stiling, 2006). In addition to the effect from the decrease in canopy cover, the lower folivore richness in the rubber agroforest may have resulted from the loss of certain insect taxa, which was observed for folivore insects of the family Chrysomelidae. This family is usually found at high richness and abundance in the canopies of tropical forests (Basset et al., 2003; Neves et al., 2013), but individuals belonging to this family were not sampled in the rubber agroforest. Huang, McAuslane, \& Nuessly, (2003) found that latex has an inhibiting effect on chrysomelid beetles when applied 
TABLE 3

Generalized linear models (GLMs) built with the abundance and richness of folivorous, sucking and xylophagous herbivorous insects sampled in cacao agroforestry matrices (CTCS and rubber) and Atlantic Forest in the municipality of Una, Southern Bahia

\begin{tabular}{llccc}
\multicolumn{1}{c}{ Response variable } & Explanatory variable & GL & Deviance & P \\
Abundance of folivorous & Canopy cover & 1 & 69.15 & $*<0.01$ \\
& Matrix & 2 & 21.55 & $* 0.04$ \\
Richness of folivorous & Canopy cover & 1 & 45.32 & $*<0.01$ \\
& Matrix & 2 & 13.82 & $* 0.02$ \\
Abundance of sap-sucking & Canopy cover & 1 & 51.51 & $* 0.02$ \\
& Matrix & 2 & 7.52 & 0.7 \\
Richness of sap-sucking & Canopy cover & 1 & 23.92 & $*<0.04$ \\
\multirow{3}{*}{ Abundance de xylophagous } & Matrix & 2 & 2.19 & 0.25 \\
& Canopy cover & 1 & 110.53 & $*<0.01$ \\
Richness of xylophagous & Matrix & 2 & 100.91 & $*<0.01$ \\
& Canopy cover & 1 & 0.85 & 0.41 \\
& Matrix & 2 & 16.30 & $*<0.02$ \\
\hline
\end{tabular}

All of the models followed a quasi-Poisson error distribution.* $\mathrm{p}<0.05$.
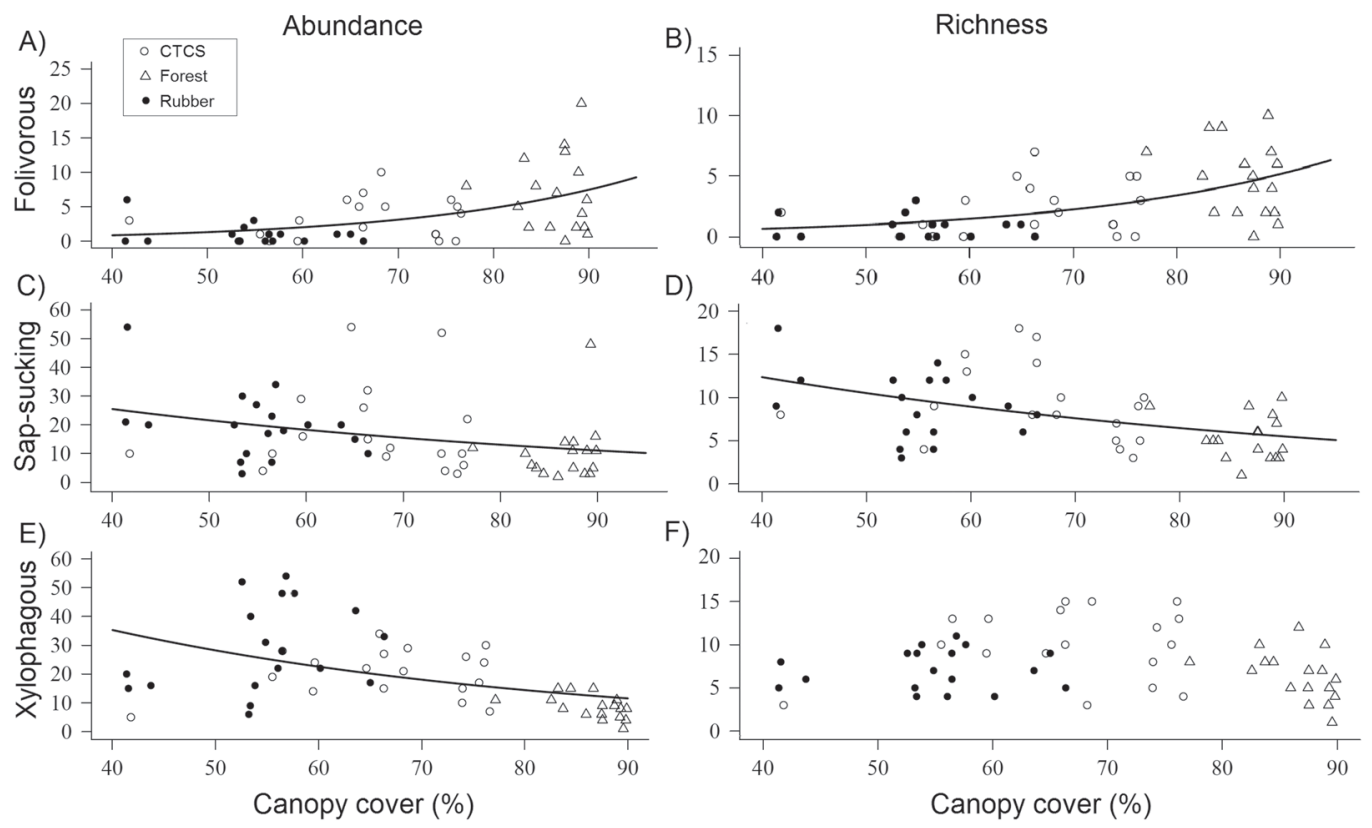

Fig. 4. Relationship between canopy cover and abundance and diversity of folivorous (A. B.), sucking (C. D.) and xylophagous (E. F.) herbivorous insects in two agroforestry matrices (CTCS and rubber) and Atlantic Forest in the cacao growing region of southeastern Bahia in the municipality of Una, Brazil.

to the surface of the leaf of its preferred host. The chrysomelids depend on the nutritional quality of the host for both feeding and progeny success (Hatcher, Paul, Ayres, \& Whittaker,
1994). Along with the reduction in resource quantity and quality, structurally simpler agroforest habitats exhibit higher temperature and lower relative humidity (Klein et al., 2002b; 
Bos et al., 2007a), which are conditions that limit the establishment and diversity of chrysomelid beetles (Zhou, Guo, Chen, \& Wan, 2010). Therefore, the folivore guild is sensitive to changes in habitat quality, and a limited number of species at low densities are observed with habitat simplification.

The composition of sap-sucking insect species was similar between the native forest and CTCS and different in the rubber agroforest. This pattern may have resulted from the increase in density of individuals of the family Psyllidae in the rubber agroforest. This family has species described as forest "pests" for several crops, especially Eucalyptus monocultures (Halbert \& Manjunath, 2004; Silva et al., 2010), mainly because of the biological characteristics of the species. Adult psyllids are typically jumpers that only fly short distances, a condition that demonstrates their low dispersal ability (Butignol \& Pedrosa-Macedo, 2003). Moreover, psyllids exhibit high reproductive rates, and females lay dozens of aggregate eggs in each reproductive event (Butignol \& Pedrosa-Macedo, 2003; Halbert \& Manjunath, 2004). The high reproductive rate facilitates rapid adaptation to a new host and leads to physical damage to the crop leaves, such as curled and deformed leaf blades, by aggregate populations. Psyllids may also act as vectors of bacteria, viruses and fungi for the host (Munyaneza, 2010). Therefore, the high density of this family in the rubber agroforest supports the hypothesis that environmental homogenization increases the risk of population outbreaks of one or several species (Schroth, Krauss, Gasparotto, Aguilar, \& Vohland, 2000; Wilby \& Thomas 2002; Bos, Steffan-Dewenter, \& Tscharntke, 2007b) that may damage the rubber trees as well as the associated cacao.

We expected the sap-sucking insect community associated with the agroforest shaded by an exotic species (rubber tree) to be less diverse compared to the habitats with native species (Brändle, Kühn, Klotz, Belle, \& Brandl, 2008) because of its close associations with the host plants (Brodbeck, Mizell III, French, Andersen, \& Aldrich, 1990). However, the sap-sucking insect richness and abundance was similar among habitats. We observed turnover and an increased frequency of species from one family of the sap-sucking guild. A different result was observed for the folivore guild, in which species abundance and richness loss occurred with simplification of the vegetation in agroforests. This pattern was observed in the increase in psyllid diversity in more homogeneous areas, especially in the rubber agroforests. Therefore, the CTCS play an important role in the conservation of sap-sucking insect community structure because species adapted to native forest conditions occur in the CTCS, despite its simpler structure.

Similar to the sap-sucking insects, xylophagous insect composition is similar between the native forest and CTCS and different between these habitats and the rubber agroforest. Although previous studies have demonstrated low host specificity in xylophagous insects (Hulcr, Mogia, Isua, \& Novotny, 2007), the colonization success of these species is determined mainly by the close relationship between larval growth and development and host quality (Heijari et al., 2008, Michaud $\&$ Grant, 2010). Therefore, the presence of latex was most likely the factor responsible for the dissimilarity in the composition of xylophagous species associated with the rubber agroforest and other habitats. Moreover, the subfamily Scolytinae dominated rubber agroforest samples and represented over $75 \%$ of the richness and $88 \%$ of the abundance of this guild. Flechtmann, Ottati, \& Berisford, (2001) found high scolytinid diversity associated with a Eucalyptus (Myrtaceae) species and exotic Pinus (Pinaceae) species. The authors suggest that these insects appear to adapt quickly to exotic plants, regardless of phylogenetic proximity with the native flora.

The intensification of agricultural management positively affected the abundance of xylophagous insects. However, this effect was a result of processes related to the specific characteristics of the agroforests and biological characteristics of this group. An example is the selection of new hosts, where many 
xylophagous insects, mostly belonging to the subfamily Scolytinae, are attracted to volatile substances emitted by the plants (Ranger, Reding, Persad, \& Herms, 2010). Additionally, the emission of volatile compounds is heightened when hosts are under certain types of stress, such as wounds (Kimmerer \& Kozlowski, 1982). Cacao plantations shaded by agroforests undergo constant management through pruning (Deitenbach, Floriani, Dubois, \& Vivan, 2008), in which the wounds become a permanent source of attraction for this guild. The shade trees of the CTCS are also subject to pruning, and a progressive removal of individual trees, to increase light entrance into the cacao plantations (Johns, 1999; Sambuichi et al., 2012), was observed during field activities conducted in this study. Finally, the higher abundance of scolytinids associated with the rubber agroforest is most likely a result of latex extraction, where periodic stem wounds become an important additional source of volatile compounds emitted into the environment, thus increasing the attraction and recruitment of individuals to these sites (Ranger et al., 2010).

In contrast to the abundance, xylophagous species richness was higher in the CTCS and similar between the native forest and rubber agroforest. Many studies have reported that habitat homogenization facilitates the colonization of several resistant but highly abundant species (McKinney \& Lockwood, 1999; Bos et al., 2007b). Therefore, we also warn that there is a potential risk of pests in rubber agroforests (Kangkamanee, Sittichaya, Ngampongsai, Permkam, \& Beaver, 2011) because many species, especially of the subfamily Scolytinae, are known to cause economic damage to crops, including cacao (Oliveira \& Luz, 2005). In addition to consuming the trunks, these species facilitate bacterial, fungal and viral infections in the hosts (Oliveira \& Luz, 2005; Cruz et al., 2009) and can ultimately affect cacao yield.

Land-use intensification through habitat homogenization and simplification from using the exotic rubber tree as shade trees, has caused shifts in the community structure of the three herbivorous insect guilds examined in this study. Consequently, in addition to the direct effect on these species, probably the intensification of agricultural management have had negative effects on the biological interactions throughout the food chain (Tscharntke, Klein, Kruess, Steffan-Dewenter, \& Thies, 2005; Gaba, Bretagnolle, Rigaud, \& Philippot, 2014). Many of these effects have involved the interruption of biological processes that sustain ecosystem functioning, such as pollination, seed dispersal, pest control and parasitism (Schroth et al., 2000; Wilby \& Thomas 2002; Tylianakis, Tscharntke, \& Klein, 2006; Otieno et al., 2011).

We found that the CTCS represent an interesting strategy when compared with planting rubber agroforests, because they maintain the herbivorous insect community in a structure that is similar to what is found in native forests of the region, thus enabling the conservation of a significant portion of folivorous, sap-sucking and xylophagous insects. The simplification of the native forest into rubber agroforests was the main cause of the shift in herbivorous insect feeding guild community structure and composition. We also emphasize about the potential risk of local pest outbreaks in regions where cacao are shaded by rubber trees and discourage this practice.

\section{ACKNOWLEDGMENTS}

We would like to thank the Dean of Research at the Federal University of Minas Gerais for partial financing of this work and for the manuscript translation support. We thank J. Lima for identification of plant species and $\mathrm{H}$. Brant, R. Mello, F. Pacelhe and G. Monteiro for field help. We thank the Coordination for the Improvement of Higher Education Personnel for research grants awarded during the development of this study. Finally, we thank the Una Biological Reserve/ Chico Mendes Institute for Biodiversity Conservation for all the physical structure and logistical support. This work was in fulfilment for the master dissertation of SMAN, and was financially supported by Brazillian National Research Council, Minas Gerais Research Support Foundation and Bahia 
Research Support Foundation DTE0036/2013 (5334/2013).

\section{RESUMEN}

Efecto del manejo de hábitat en diferentes gremios alimentarios de insectos herbívoros en sistemas agroforestales de cacao. La presión humana sobre los hábitats naturales aumenta la importancia de los sistemas agroforestales para la conservación de la biodiversidad. El objetivo de este estudio fue evaluar el papel del sistema tradicional de cultivo de cacao en la conservación de la comunidad de insectos herbívoros en comparación con el agrobosque monodominante de caucho, un tipo de sistema agrícola para el cultivo de cacao. Los insectos fueron muestreados en tres hábitats en el sureste de Bahia, Brasil: bosque nativo, sistema tradicional de cultivo de cacao y agrobosque de caucho. En cada hábitat, se establecieron 18 parcelas de $10 \mathrm{~m}^{2}$, se tomaron medidas estructurales y se muestrearon los insectos herbívoros con una trampa tipo Malaise. La diversidad de folívoros disminuyó con la simplificación de la estructura de la vegetación, pero la composición de especies fue similar entre hábitats. Además se presentó una disminución de la disponibilidad de recursos en agrobosques de caucho, el látex presente en estos sistemas han limitado la aparición de especies que no pueden evadir la toxicidad de látex. La diversidad de insectos chupadores de savia fue similar entre los hábitats, pero la composición de especies fue similar sólo en el sistema tradicional de cultivo de cacao y el bosque nativo, y diferente en el agrobosque de caucho. Hemos observado que hay una mayor frecuencia de individuos de la familia Psyllidae en el agrobosque de caucho. La biología y el comportamiento de los psílidos y ausencia de enemigos naturales permiten que su diversidad aumente cuando se adaptan a un nuevo huésped. Hemos observado un cambio en la composición de los insectos xilófagos en el agrobosque de caucho en comparación con la de otros hábitats. Por otra parte, este agrobosque tiene una baja riqueza de especies, pero gran abundancia individual. La extracción de látex probablemente es una fuente adicional importante de compuestos volátiles que son vertidos en el ambiente, y aumenta la atracción y el reclutamiento de curculiónidos en estos sitios. Hemos llegado a la conclusión de que el sistema tradicional de cultivo de cacao tiene una comunidad de insectos herbívoros con una estructura similar a la comunidad que se encuentra en los bosques nativos de la región, y presenta una estrategia de conservación más interesante si se compara con los sistemas agroforestales de caucho. También hicimos hincapié en el riesgo potencial de aparición de plagas locales en sistemas agroforestales de caucho, tanto para el caucho como para los árboles de cacao asociados.

Palabras clave: Theobroma cacao, biodiversidad, uso de suelo, conservación, manejo de bosques.

\section{REFERENCES}

Agrawal, A. A., \& Konno, K. (2009). Latex: a model for understanding mechanisms, ecology, and evolution of plant defense against herbivory. Annual Review Ecology Evolution Systematics, 40, 311-331.

Agrawal, A. A., \& Kotanen, P. M. (2003). Herbivores and the success of exotic plants: a phylogenetically controlled experiment. Ecology Letters, 6, 712-715.

Agrawal, A. A., \& Van Zandt, P. A. (2003). Ecological play in the coevolutionary theater: genetic and environmental determinants of attack by a specialist weevil on milkweed. Journal of Ecology, 91, 1049-1059.

Alger, K., \& Caldas, M. (1994). The declining cocoa economy and the Atlantic Forest of Southern Bahia, Brazil: conservation attitudes of cocoa planters. Environmentalist, 14, 107-119.

Anderson, M. J. (2001). A new method for non-parametric multivariate analysis of variance. Austral Ecology, 26, 32-46.

Araujo, M., Alger, K., Rocha, M., \& Mequita, C. A. B. (1998). A Mata Atlântica do Sul da Bahia-situação atual, ações e perspectivas. Serie Cadernos Reserva Biosfera Mata Atlântica, 8, 1-35.

Awmack, C. S., \& Leather, S. R. (2002). Host plant quality and fecundity in herbivorous insects. Annual Review of Entomology, 47(1), 817-844.

Basset, Y. 1988. A composite interception trap for sampling arthropods in tree canopies. Journal of the Australian Entomological Society, 27, 213-219.

Basset, Y., Novotny, V., Miller, S. E., \& Kitching, R. L. (2003). Arthopods of Tropical Forests: spatiotemporal dynamics \& resource use in the canopy. Cambridge: Cambridge University Press.

Bos, M. M., Höhn, P., Shahabuddin, S., Buchori, D., Steffan-Dewenter, I., \& Tscharntke, T. (2007a). Insect responses to forest conversion and agroforestry management. In T. Tscharntke, C. Leuschner, E. Guhardja, \& M. Zeller (Eds), The stability of tropical rainforest margins: linking ecological, economic and social constraints of land-use and conservation (pp. 279-296). Berlin: Springer.

Bos, M. M., Steffan-Dewenter, I., \& Tscharntke, T. (2007b). Shade tree management affects fruit abortion, insect pests and pathogens of cacao. Agriculture, ecosystems \& environment, 120(2), 201-205.

Bos, M. M., Steffan-Dewenter, I., \& Tscharntke, T. (2007c). The contribution of cacao agroforests to the conservation of lower canopy ant and beetle diversity in Indonesia. Biodiversity and Conservation, 16(8), 2429-2444. 
Brändle, M., Kühn, I., Klotz, S., Belle, C., \& Brandl, R. (2008). Species richness of herbivores on exotic host plants increases with time since introduction of the host. Diversity and Distributions, 14, 905-912.

Brodbeck, B. V., Mizell III, R. F., French, W. J., Andersen, P. C., \& Aldrich, J. H. (1990). Amino acids as determinants of host preference for the xylem feeding leafhopper, Homalodisca coagulata. Oecologia, 83, 338-345.

Butignol, C. A., \& Pedrosa-Macedo, J. H. (2003). Biologia de Neotrioza tavaresi Crawford, 1925 (Hemiptera, Psyllidae), galhador da folha do araçazeiro (Psidium cattleianum). Revista Brasileira de Entomologia, 47(1), 1-7.

Cassano, C. R., Schroth, G., Faria, D., Delabie, J. H. C., \& Bede, L. (2008). Landscape and farm scale management to enhance biodiversity conservation in the cocoa producing region of southern Bahia, Brazil. Biodiversity and Conservation, 18, 577-603.

Cornelissen, T., \& Stiling, P. (2006). Responses of different herbivore guilds to nutrient addition and natural enemy exclusion. Ecoscience, 13(1), 66-74.

Crawley, M. J. (2007). The R Book. (1th ed.). Jhon Willey \& Sons Ltd.

Cruz, P. L., Equihua-Martínez, A., Romero-Nápoles, J., Sánchez, S., García-López, E., \& Bravo-Mojica, H. (2009). Escolítidos (Coleoptera: Scolytidae) asociados al agroecosistema cacao en Tabasco, México. Neotropical Entomology, 38(5), 602-609.

Deitenbach, A., Floriani, G., Dubois, J., \& Vivan, J. (2008). Manual agroflorestal para a Mata Atlântica. Brasília: Ministério do Desenvolvimento Agrário, Secretaria de Agricultura Familiar.

Díaz, S., Lavorel, S., de Bello, F., Quétier, F., Grigulis, K., \& Robson, T. M. (2007). Incorporating plant functional diversity effects in ecosystem service assessments. Proceedings of the National Academy of Sciences, 104(52), 20684-20689.

Flechtmann, C. A. H., Ottati, A. L. T., \& Berisford, C. W. (2001). Ambrosia and bark beetles (Scolytidae: Coleoptera) in pine and eucalypt stands in southern Brazil. Forest Ecology and Management, 142(1), 183-191.

Fonseca, G. A. B., Alger, K., Pinto, L. P., Araujo, M., \& Cavalcanti, R. (2004). Corredores de biodiversidade: o corredor central da Mata Atlântica. In M. B. Arruda, L. F. S. N. Sá (Eds.), Corredores Ecológicos: uma Abordagem Integradora de Ecossistemas no Brasil (pp 47-65). Brasília: IBAMA.

Frazer, G., Canham, C., \& Lertzman, K. (1999). Light Analyzer (GLA), Version 2.0: Imaging software to extract canopy structure and gap light transmission indices from true-colour fisheye photographs, users manual and program documentation. New York: Simon Fraser University, Burnaby, British Columbia, and the Institute of Ecosystem Studies, Millbrook.

Fundação SOS Mata Atlântica, Instituto Nacional de Pesquisas Espaciais. (2008). Atlas dos remanescentes florestais da Mata Atlântica período 2000-2005. São Paulo: Fundação SOS Mata Atlântica/INPE.

Gaba, S., Bretagnolle, F., Rigaud, T., \& Philippot, L. (2014). Managing biotic interactions for ecological intensification of agroecosystems. Agroecology and Land Use Systems, 2, 1-9.

Halbert, S. E., \& Manjunath, K. L. (2004). Asian citrus psyllids (Sternorrhyncha: Psyllidae) and greening disease of citrus: a literature review and assessment of risk in Florida. Florida Entomologist, 87(3), 330-353.

Hatcher, P. E., Paul, N. D., Ayres, P. G., \& Whittaker, J. B. (1994). The effect of a foliar disease (rust) on the development of Gastrophysa viridula (Coleoptera: Chrysomelidae). Ecological Entomology, 19(4), 349-360.

Heijari, J., Nerg, A. M., Kainulainen, P., Noldt, U., Levula, T., Raitio, H., \& Holopainen, J. K. (2008). Effect of long-term forest fertilization on Scots pine xylem quality and wood borer performance. Journal of Chemical Ecology, 34(1), 26-31.

Huang, J., McAuslane, H. J., \& Nuessly, G. S. (2003). Resistance in lettuce to Diabrotica balteata (Coleoptera: Chrysomelidae): the roles of latex and inducible defense. Environmental Entomology, 32(1), 9-16.

Hulcr, J., Mogia, M., Isua, B., \& Novotny, V. (2007). Host specificity of ambrosia and bark beetles (Col., Curculionidae: Scolytinae and Platypodinae) in a New Guinea rainforest. Ecological Entomology, 32, 762-772.

Johns, N. D. (1999). Conservation in Brazil's chocolate forest: the unlikely persistence of the traditional cocoa agroecosystem. Environmental Management, $23,31-47$

Kangkamanee, T., Sittichaya, W., Ngampongsai, A., Permkam, S., \& Beaver, R. A. (2011). Wood-boring beetles (Coleoptera: Bostrichidae, Curculionidae; Platypodinae and Scolytinae) infesting rubber wood sawn timber in southern Thailand. Journal of Forest Research, 16(4), 302-308.

Kessler, M., Abrahamczyk, S., Bos, M., Buchori, D., Putra, D. D., Gradstein, S. R., ... Tscharntke, T. (2009). Alpha and beta diversity of plants and animals along a tropical land-use gradient. Ecological Applications, $19,2142-2156$.

Kimmerer, T. W., \& Kozlowski, T. T. (1982). Ethylene, ethane, acetaldehyde, and ethanol production by plants under stress. Plant Physiology, 69, 840-847. 
Klein, A. M., Steffan-Dewenter, I., Buchori, D., \& Tscharntke, T. (2002a). Effects of land-use intensity in tropical agroforestry systems on flower-visiting and trap-nesting bees and wasps. Conservation Biology, 16, 1003-1014.

Klein, A. M., Steffan-Dewenter, I., \& Tscharntke, T. (2002b). Predator-prey ratios on cocoa along a landuse gradient in Indonesia. Biodiversity and Conservation, 11(4), 683-693.

Lewinsohn, T. M. (1991). The geographical distribution of plant latex. Chemoecology, 2, 64-68.

Marques, J. R. B., \& Monteiro, W. R. (2006). Adoção do sistema agroflorestal cacau $\mathrm{x}$ seringa-melhoria de condições de cultivo e agregação de valores. In $28^{a}$ Semana do Fazendeiro (pp. 9-14). Itabuna: CEPLAC/ CENEX/EMARC.

McKinney, M. L., \& Lockwood, J. L. (1999). Biotic homogenization: a few winners replacing many losers in the next mass extinction. Trends in Ecology \& Evolution, 14(11), 450-453.

Michaud, J. P., \& Grant, A. K. (2010). Variation in fitness of the longhorned beetle, Dectes texanus, as a function of host plant. Journal of Insect Science, $10,1-14$

Moran, C. V., \& Southwood, T. R. E. (1982). The guild composition of arthropod communities in trees. Journal of Animal Ecology, 51, 289-306.

Mori, S. A. (1989). Eastern Extra-Amazonian Brasil. In D. G. Campbell, H. D. Hammond (Eds.), Floristic Inventory of Tropical Countries: The Status of Plant Systematics, Collections, and Vegetation, Plus Recommendations for the Future (pp. 427-455). NY: The New York Botanical Garden.

Munyaneza, J. E. (2010). Psyllids as vectors of emerging bacterial diseases of annual crops. Southwestern Entomologist, 35(3), 471-477.

Myers, N., Mittermeier, R. A., Mittermeier, C. G., Fonseca, G. A., \& Kent, J. (2000). Biodiversity hotspots for conservation priorities. Nature, 403, 853-858.

Neves, F. S., Silva, J. O., Espírito-Santo, M. M., \& Fernandes, G. W. (2014). Insect Herbivores and Leaf Damage along Successional and Vertical Gradients in a Tropical Dry Forest. Biotropica, 46(1), 14-24.

Neves, F. S., Sperber, C. F., Campos, R. I., Soares, J. P., \& Ribeiro, S. P. (2013). Contrasting effects of sampling scale on insect herbivores distribution in response to canopy structure. Revista de Biología Tropical, 61(1), 125-137.

Oliveira, M. D., \& Luz, E. D. M. N. (2005). Identificação e manejo das principais doenças do cacaueiro no Brasil. Ilhéus: CEPLAC/CEPEC/SEFIT.
Otieno, M., Woodcock, B. A., Wilby, A., Vogiatzakis, I. N., Mauchline, A. L., Gikungu, M. W., \& Potts, S. G. (2011). Local management and landscape drivers of pollination and biological control services in a Kenyan agro-ecosystem. Biological Conservation, 144(10), 2424-2431.

Pardini, R., Faria, D., Accacio, G. M., Laps, R. R., Mariano-Neto, E., Paciencia, M. L. B., Dixo, M., \& Baumgarten, J. (2009). The challenge of maintaining Atlantic forest biodiversity: A multi-taxa conservation assessment of specialist and generalist species in an agro-forestry mosaic in southern Bahia. Biological Conservation, 142, 1178-1190.

Peiera, J. L., Ram, A., Figueiredo, J. M., \& Almeida, L. C. C. (1990). First occurrence of witches' broom disease in the principal cocoa-growing region of Brazil. Tropical Agriculture, 67(2), 188-189.

Perfecto, I., Mas, A., Dietsch, T., \& Vandermeer, J. (2003). Conservation of biodiversity in coffee agroecosystems: a tri-taxa comparison in southern Mexico. Biodiversity and Conservation, 12, 1239-1252.

Polis, G. A., \& Strong, D. R. (1996). Food web complexity and community dynamics. American Naturalist, 813-846.

Price, P. W., Bouton, C. E., Gross, P., McPheron, B. A., Thompson, J. N., \& Weis, A. E. (1980). Interactions among three trophic levels: influence of plants on interactions between insect herbivores and natural enemies. Annual Review of Ecology and Systematics, 11, 41-65.

R Development Core Team. (2014). R: A language and environment for statistical computing. Version 2.13. User's guide and application published: http:// www.R-project.org.

Rafael, J. A., Melo, G. A. R., Carvalho, C. J. B., Casari, S. A., \& Constantino, R. (2012). Insetos do Brasil: Diversidade e Taxonomia. Ribeirão Preto: Holos Editora.

Ranger, C. M., Reding, M. E., Persad, A. B., \& Herms, D. A. (2010). Ability of stress-related volatiles to attract and induce attacks by Xylosandrus germanus and other ambrosia beetles. Agricultural and Forest Entomology, 12(2), 177-185.

Rice, R. A., \& Greenberg, R. (2000). Cacao cultivation and the conservation of biological diversity. Ambio, $29,167-173$

Saatchi, S., Agosti, D., Alger, K., Delabie, J., \& Musinsky, J. (2001). Examining fragmentation and loss of primary forest in the southern bahian atlantic forest of brazil with radar imagery. Conservation Biology, $15,867-875$

Sala, O. E., Chapin, F. S., Armesto, J. J., Berlow, E., Bloomfield, J., Dirzo, R., ...Wall, D. H. (2000). 
Global biodiversity scenarios for the year 2100 . Science, 287(5459), 1770-1774.

Sambuichi, R. H., Vidal, D. B., Piasentin, F. B., Jardim, J. G., Viana, T. G., Menezes, A. A., ...Baligar, V. C. (2012). Cabruca agroforests in southern Bahia, Brazil: tree component, management practices and tree species conservation. Biodiversity and Conservation, 21(4), 1055-1077.

Sanchez-Azofeifa, G. A., Kalacska, M. E. R., Gamon, J., Rodriguez, J. P., Lawrence, D., Dutchak, K., ... Human., Y. H. (2007). Ecological and Biophysical Dimension of Tropical Dry Forest. Manual of Methods, 48-104.

Schroth, G., Krauss, U., Gasparotto, L., Aguilar, J. D., \& Vohland, K. (2000). Pests and diseases in agroforestry systems of the humid tropics. Agroforestry Systems, 50(3), 199-241.

Schulze, C. H, Waltert, M., Kessler, P. J. A., Pitopang, R., Shahabuddin, Veddeler, D., ...Tscharntke, T. (2004). Biodiversity indicator groups of tropical land use systems: comparing plants, birds and insects. Ecological Applications, 14, 1321-1333.

Silva, J. O., Oliveira, K. N., Santos, K. J., Espírito-Santo, M. M., Neves, F. S., \& Faria, M. L. (2010). Efeito da Estrutura da Paisagem e do Genótipo de Eucalyptus na Abundância e Controle Biológico de Glycaspis brimblecombei Moore (Hemiptera: Psyllidae). Neotropical Entomology, 39, 91-96.

Sperber, C., Nakayama, K., Valverde, M. J., \& Neves, F. S. (2004). Tree species richness and density affect parasitoid diversity in cacao agroforestry. Basic and Applied Ecology, 5, 241-251.

Steffan-Dewenter, I., Kessler, M., Barkmann, J., Bos, M. M., Buchori, D., Erasmi, S., ...Tscharntke, T. (2007). Tradeoffs between income, biodiversity, and ecosystem functioning during tropical rainforest conversion and agroforestry intensification. Proceedings of the National Academy of Sciences of the United States of America, 104(12), 4973-4978.

Stein, A., Gerstner, K., \& Kreft, H. (2014). Environmental heterogeneity as a universal driver of species richness across taxa, biomes and spatial scales. Ecology letters, 17(7), 866-880.

Strong, D. R., Lawton, J. H., \& Southwood, T. R. E. (1984). Insects on plants. Community patterns and mechanisms. London: Blackwell.

Tabarelli, M., Peres, C. A., \& Melo, F. P. (2012). The 'few winners and many losers' paradigm revisited: Emerging prospects for tropical forest biodiversity. Biological Conservation, 155, 136-140.

Thomas, W. (2003). Natural vegetation types in southern Bahia. In P. I. Prado (Eds.), Corredor De Biodiversidade Da Mata Atlântica Do Sul Da Bahia. Publicação Em CDROM, Ilhéus, IESB/CI/CABS/UFMG/ UNICAMP.

Tscharntke, T., Klein, A. M., Kruess, A., Steffan-Dewenter, I., \& Thies, C. (2005). Landscape perspectives on agricultural intensification and biodiversity-ecosystem service management. Ecology letters, 8(8), 857-874

Tylianakis, J. M., Tscharntke, T., \& Klein, A. M. (2006). Diversity, ecosystem function, and stability of parasitoid-host interactions across a tropical habitat gradient. Ecology, 87(12), 3047-3057.

Weis, A. E., \& Berenbaum, M. R. (1989). Herbivorous insects and green plants. In W. G. Abrahamson (Ed.): Plant-animal Interactions (pp. 123-162). New York: McGraw Hill-Book.

Wilby, A., Heong, K. L., Huyen, N. P. D., Quang, N. H., Minh, N. V., \& Thomas, M. B. (2006). Arthropod diversity and community structure in relation to land use in the Mekong delta, Vietnam. Ecosystems, 9(4), 538-549.

Wilby, A., \& Thomas, M. B. (2002). Natural enemy diversity and pest control: patterns of pest emergence with agricultural intensification. Ecology Letters, 5(3), 353-360.

Zhou, Z. S., Guo, J. Y., Chen, H. S., \& Wan, F. H. (2010). Effect of humidity on the development and fecundity of Ophraella communa (Coleoptera: Chrysomelidae). BioControl, 55(2), 313-319. 
